\title{
Estimation of effect of breeding bulls and genetic parameters on early growth performance of calves at farm and field levels
}

\author{
S I slam ${ }^{1}$, MA Hoque* ${ }^{1}$, MAMY Khandoker ${ }^{1}$, NG Saha ${ }^{1,2}$, A Akhtar ${ }^{1,3}$ \\ ${ }^{1}$ Department of Animal Breeding and Genetics, Bangladesh Agricultural University, Mymensigh \\ 2202; 'Department of Animal Science and Nutrition, Patuakhali Science and Technology University, Babugonj, \\ Barisal; ${ }^{3}$ Department of Livestock Services, Dhaka 1215, Bangladesh
}

\begin{abstract}
The present study was conducted using records on four breeding bulls maintained at the Artificial Insemination ( $\mathrm{Al}$ ) Center of Bangladesh Agricultural University (BAU), Mymensingh and on 154 of their progeny maintained at BAU Dairy Farm (112) and some villages (42 progeny) adjacent to BAU for estimating the effect of breeding bulls and genetic parameters on early growth performance of the progeny at farm and field levels. Genetic correlations between traits of bulls and their progeny were also estimated. Bull traits were metabolic body weight (MWT), feed intake (FI) and residual feed intake (RFI) where progeny traits were birth weight (BWT), final body weight (FWT) at 90 days of age and average daily gain (ADG). Mean BWT of progeny at farm and field level was $16.34 \pm 1.85$ to $17.62 \pm 1.97 \mathrm{~kg}$ and $13.89 \pm 2.78$ to $16.11 \pm 2.98 \mathrm{~kg}$, respectively. The FWT at farm progeny was $48.9 \pm 2.87$ to $55.67 \pm 2.14 \mathrm{~kg}$ whereas $43.43 \pm 2.50$ to $52.22 \pm 3.34 \mathrm{~kg}$ for field progeny. The ADG at farm and field progeny was $0.36 \pm 0.03$ to $0.43 \pm 0.01$ and $0.32 \pm 0.03$ to $0.42 \pm 0.03 \mathrm{~kg}$, respectively. The BWT and FWT of farm progeny were significantly $(p>0.05)$ higher than the progeny of field level. Breeding bulls had significant $(p<0.05)$ effect on FWT and ADG for both of the farm and field progeny. Estimated heritability was found to be moderate in case of BWT $(0.32 \pm 0.19)$, but low for FWT $(0.26 \pm 0.18)$ and ADG $(0.29 \pm 0.20)$ for pooled average. The genetic correlation between bulls' MWT and BWT was high $\left(r_{g}=0.54 \pm 0.17\right)$, but low with FWT $\left(r_{g}=0.26 \pm 0.18\right)$ and ADG $\left(r_{g}=0.28 \pm 0.23\right)$. Moderate in daily FI of bulls was genetically correlated with BWT $(0.45 \pm 0.22)$, FWT $(0.38 \pm 0.24)$ and ADG $(0.35 \pm 0.25)$ for their progeny, while low but favorable negative genetic correlation $\left(r_{g}=-0.13 \pm 0.17\right)$ was observed between ADG of progeny and RFI of bulls. The negative correlation for RFI with ADG suggested that selection might result in better success in improving herd production efficiency without compromising progeny growth performance.
\end{abstract}

Key words: Breeding bulls, genetic parameters, growth traits, progeny, residual feed intake Bangladesh Animal Husbandry Association. All rights reserved. $\quad$ Bang. J. Anim. Sci. 2013. 42(2): 81-88

\section{Introduction}

The cattle are most promisingly inseparable and integral part of existing farming system of Bangladesh. Although concentration of cattle in Bangladesh is high, but their productivity is low mainly due to inadequate feed supply and low genetic potentiality. As a result their growth performance is very poor. In this situation to get quality progeny for increasing milk and beef production, superior breeding bull may be considered as important factor. There are many cost-worthy matters involved with cattle improvement for milk and beef production. In many of the cases, profitability depends on the efficient and productive use of feed. As a result feed efficient breeding bulls selection may be considered as major factor, because 80 to $90 \%$ of the genetic improvement comes through the sires and bull passes on superior genetics for feed efficiency to its progeny which might be realized as feed saving for calves in the feedlot and for replacement heifers entering the herd (Trejo, 2010). It might be beneficial to estimate effect of reducing extra feed intake of bull on progeny growth performances which will be helpful to take decision in breeding program. Residual feed intake (RFI) is receiving greater attention as the preferred feed efficiency measure due to its favorable or negligible phenotypic and genetic relationships with feed intake, daily gain, FCR, and body weight (Arthur et al. 2001a,b; Hoque et al. 2006; Ahola et al. 2007). The RFI analysis among cattle is defined as the difference between the actual feed intake and the expected feed intake of each animal was first proposed as an alternative measure of feed efficiency by Koch et al. (1963). Inefficient animals will eat more than expected and their RFI value will be positive or high (Lancaster et al. 2005). The early study 


\section{Effect of breeding bulls and genetic parameters on progeny growth}

(Aktar et al. 2011) has so far been carried out on farm progeny and their sire evaluation and considering the aforesaid matters, this study was made to evaluate the effect of breeding bulls on their progeny early growth performance at farm and field levels and to estimate the relationships between progeny and sire traits along with genetic parameters for early growth traits of progeny tested at farm and field levels.

\section{Materials and Methods}

The experiment was conducted partly at the Artificial Insemination (Al) Center under the Department of Animal Breeding and Genetics and the dairy farm (DF) under the Department of Dairy Science of BAU, Mymensingh. Besides, at farmers' level, data were collected from some villages adjacent to BAU namely Boera, Digharkanda, Shikarikanda and Bhabakhali. Bull performance (feed intake and body weight) data were used during the period from January, 2010 to December, 2010 (Aktar et al. 2011). Performance records on progeny (birth weight and weight at 3 months of age) were collected from DF during the period from January, 2011 to December, 2011. The information on field progeny (birth weight and weight at 3 months of age) were collected separately with the help of the cow's owner for each of the progeny from respective cows inseminated by the semen of the experimental bulls at Al centre.

Breeding bulls were stall-fed and uniformly provided with $50 \%$ green grass and $50 \%$ straw on live weight basis in addition to a concentrate mixture of mustard oil cake, wheat bran and common salt at the rate of $1 \mathrm{~kg} /$ bull/day. Roughages (green grass and straw) and concentrate feeds were supplied twice daily in the morning and evening. Fresh water was provided ad libitum. Monthly body weights of breeding bulls were recorded using the portable weighing balance. Average metabolic body weight, daily feed intake and residual feed intake of the breeding bulls estimated by Aktar et al. (2011) at Al center are presented in Table 1. Bull performance traits were recorded for daily feed intake, metabolic body weight and RFI. Daily feed intake was measured by the difference between supplied and leftover feed. Metabolic body weight was calculated likewise the MWT and raised to the power of 0.75 as $\mathrm{MWT}^{0.75}$. The residual feed intake (RFI) may be calculated from the difference between the animal's actual intake and what quantify of feed supplied as RFI = Actual intake - Predicted intake. But in present study, the RFI was estimated as the difference between actual feed intake and that predicted from single trait analysis for daily feed intake with metabolic body weight using Statistical Analysis system (SAS) software as described by Hoque and Oikawa (2004) as follows:

\section{RFI = FI - MWT $\times \boldsymbol{\beta}_{\mathbf{w}}$ - Intercept}

where, RFI = Residual feed intake, FI = Daily feed intake, MWT = Metabolic body weight, $\beta_{\mathrm{w}}=$ Regression coefficients of animal's FI on MWT.

\section{Farm and field progeny management}

The calves born at BAU Dairy Farm were reared. Farm progeny were reared in groups in the calf shed, and provided them a plenty of green grass and ad libitum water. Concentrate feeds were also supplied to them twice daily in the morning and evening. A regular vaccination and medication were given to each of the calf. Due to illiteracy and lack of credit facilities, village farmers were incapable of rearing their animals scientifically. Calves were born and grown in various farmers house of selected villages. No special treatments were given to the field progeny as progeny reared at farm. Moreover, feed scarcity and cost of feed was the liable factor for poor feeding management of field progeny as well.

Table 1. Average metabolic body weight, daily feed intake and residual feed intake of the breeding bulls at $\mathrm{Al}$ center (Aktar et al. 2011)

\begin{tabular}{llllll}
\hline Bull & Genotype & Age of bull & \multicolumn{3}{l}{ Mean \pm SE $(332)^{*}$} \\
\cline { 3 - 5 } ID & & & MWT $(\mathrm{kg})$ & $\mathrm{FI}(\mathrm{kg} /$ day $)$ & $\mathrm{RFI}(\mathrm{kg} / \mathrm{day})$ \\
\hline 122 & Sindhi cross & 8.50 years & $106.05 \pm 2.28$ & $24.14^{\mathrm{b}} \pm 2.77$ & $-0.37 \pm 0.07$ \\
131 & Friesian cross & 8.25 years & $97.10 \pm 1.62$ & $23.97^{\mathrm{b}} \pm 2.87$ & $0.31 \pm 0.05$ \\
143 & Sahiwal cross & 4.5 years & $92.88 \pm 1.22$ & $22.85^{\mathrm{a}} \pm 2.88$ & $-0.29 \pm 0.07$ \\
2858 & Friesian cross & 5.4 years & $102.36 \pm 1.31$ & $24.82^{\mathrm{c}} \pm 2.66$ & $0.54 \pm 0.06$ \\
\hline
\end{tabular}

*No. of observations $(n=322)$ for each bull; ID, identity; SE, standard error; MWT, metabolic body weight; $\mathrm{FI}$, feed intake; RFI, residual feed intake. Means with different superscripts within the same column differed significantly $(p<0.05)$ 
Hoque et al. (2013) Bang. J. Anim. Sci. 42 (2): 81 - 88

\section{Data structure and information collection}

Four breeding bulls of BAU Al centre, and 112 and 42 of their progeny from the farm and field levels were evaluated for performance records. Among the 4 bulls, 2 were Friesian crosses (ID No. 131 and ID No. 2858), 1 of Sindhi crosses (ID No. 122.), and 1 of Sahiwal crosses (ID No. 143). In case of field progeny, the sire-damcalves records were collected from the register book of Al centre. The birth weight and final weight ( 90 days of age) of the progeny resultant from the breeding bulls of Al center for both of the farm and field levels were measured by using the digital portable weighing balance and data were recorded during the study period from January-December, 2011. The information of those calves born before the study period (20052010) were also collected from the herd book of BAU dairy farm and recorded. The average daily gain for calves was calculated from the difference between birth weight and final weight (90 days weight), and finally dividing it by the number of days (90).

\section{Statistical analysis}

The analyses of variances were estimated using the Statistical Analysis System (SAS, 1998) computer program. A pedigree file was constructed for estimating the heritability and genetic correlation. The covariance for genetic correlation was estimated by the Residual Maximum Likelihood (REML) method with the Variance Component Estimate (VCE) program (Neumarier and Groeneveld, 1998). The covariance components were estimated in a series of two-trait animal models (one bull trait and one progeny trait or one field progeny trait and one farm progeny trait).

Covariance structure for additive genetic effects of animals and residual effects:

$$
\operatorname{Var}\left(\begin{array}{l}
a_{1} \\
a_{2} \\
e_{1} \\
e_{2}
\end{array}\right)=\left[\begin{array}{cccc}
A \sigma_{a 1}^{2} & A \sigma_{a 12} & \mathbf{0} & \mathbf{0} \\
& A \sigma_{a 2}^{2} & \mathbf{0} & \mathbf{0} \\
& & I \sigma_{e 1}^{2} & I \sigma_{e 12} \\
\text { sym. } & & & I \sigma_{e 2}^{2}
\end{array}\right]
$$

where, $a_{1}$ and $a_{2}$ are the vectors of additive genetic effects of animal for a bull trait and a progeny trait, respectively, and $e_{1}$ and $e_{2}$ are the residual effects for them. $A$ is the numerator relationship matrix consisting of the genetic relationships between animals. The $\sigma_{2} a_{1}$ and $\sigma_{2} \mathrm{a}_{2}$ are the additive genetic variances for a bull trait and a progeny trait, respectively, and $\sigma_{2} \mathrm{a}_{12}$ is the additive covariance for them. The $\sigma_{2} e_{1}$ and $\sigma_{2} e_{2}$ are the residual variances for a bull trait and a progeny trait, respectively, and $\sigma_{2} a_{12}$ is the residual covariance for them. Since the two traits were recorded on different animals, the $\sigma_{2} a_{12}$ was assumed to be zero.

\section{Results}

\section{Progeny performance}

Table 2 and 3 show the average BWT, FWT and ADG for male and female along with pooled average, and Table 4 shows the mean BWT, FWT and ADG (Ignoring sex \& sire group, and ignoring sire group) of progeny at farm and field levels. The average BWT was $16.67 \pm 2.34$ and $14.62 \pm 3.45 \mathrm{~kg}$ of calves for Sindhi cross (122), $17.62 \pm 1.97$ and $16.11 \pm 2.98 \mathrm{Kg}$ for Friesian cross (131), $16.34 \pm 1.85$ and $14.13 \pm 3.45 \mathrm{~kg}$ for Sahiwal cross (143), and $16.99 \pm 1.77$ and $13.89 \pm 2.78 \mathrm{~kg}$ for Friesian cross (2858) at farm and field levels, respectively. Similarly, FWT was $48.9 \pm 2.87$ and $43.43 \pm 2.50 \mathrm{~kg}$ of calves for bull $122,55.57 \pm 2.45$ and $50.62 \pm 2.93 \mathrm{~kg}$ for 131 , $50.78 \pm 2.34$ and $52.22 \pm 3.34 \mathrm{~kg}$ for 143 , and $55.67 \pm 2.14$ and $51.44 \pm 3.87 \mathrm{~kg}$ for 2858 at farm and field levels, respectively. Daily gain of calves at farm vs. field progeny were $358.22 \pm 33.46$ and $320.1 \pm 32.50 \mathrm{~g}$ for bull 122 , $421.67 \pm 31.34$ and $383.44 \pm 34.21 \mathrm{~g}$ for 131 , $382.67 \pm 27.13$ and $423.22 \pm 29.56 \mathrm{~g}$ for 143 , and $429.78 \pm 13.67$ and $417.23 \pm 42.30 \mathrm{~g}$ for 2858, respectively. With ignoring sex and sire group, the mean BWT, FWT and ADG were $16.94^{\mathrm{a}} \pm 1.96$ and $14.70^{\mathrm{b}} \pm 1.86 \mathrm{~kg}, 52.32^{\mathrm{a}} \pm 2.10$ and $49.20 \pm 1.98 \mathrm{~kg}$, and $393.11 \pm 29.21$ and $383.29 \pm 27.77 \mathrm{~g}$ at farm and field levels, respectively. However, ignoring sire group the mean BWT, FWT and ADG were $18.38 \pm 2.24$ and $16.16 \pm 3.04 \mathrm{~kg}, 54.16 \pm 2.66$ and 51.48 $\pm 2.99 \mathrm{~kg}, 408.59 \pm 29.35$ and $392.32 \pm 33.36 \mathrm{~g}$ for male, and $15.55 \pm 3.07$ and $12.75 \pm 3.33 \mathrm{~kg}$, $50.60 \pm 2.95$ and $46.17 \pm 3.54 \mathrm{~kg}, 388.62 \pm 31.82$ and $371.25 \pm 34.40 \mathrm{~g}$ for female at farm and field levels, respectively. 


\section{Effect of breeding bulls and genetic parameters on progeny growth}

Table 2. Average birth weight, final weight and daily gain of progeny of the different bulls at farm levels

\begin{tabular}{|c|c|c|c|c|c|c|c|c|c|}
\hline \multirow{2}{*}{$\begin{array}{l}\text { Bull } \\
\text { ID }\end{array}$} & \multicolumn{3}{|c|}{ Male } & \multicolumn{3}{|c|}{ Female } & \multicolumn{3}{|c|}{ Pooled } \\
\hline & $\begin{array}{c}\mathrm{BWT} \pm \mathrm{SE} \\
(\mathrm{kg})\end{array}$ & $\begin{array}{c}\mathrm{FWT} \pm \mathrm{SE} \\
(\mathrm{kg})\end{array}$ & $\begin{array}{c}A D G \pm S E \\
\text { (g/day) }\end{array}$ & $\begin{array}{c}\mathrm{BWT} \pm \mathrm{SE} \\
(\mathrm{kg})\end{array}$ & $\begin{array}{c}\mathrm{FWT} \pm \mathrm{SE} \\
(\mathrm{kg})\end{array}$ & $\begin{array}{c}A D G \pm S E \\
(g / d)\end{array}$ & $\begin{array}{c}\mathrm{BWT} \pm \mathrm{SE} \\
(\mathrm{kg})\end{array}$ & $\begin{array}{c}\mathrm{FWT} \pm \mathrm{SE} \\
(\mathrm{kg})\end{array}$ & $\begin{array}{c}A D G \pm S E \\
(g / d)\end{array}$ \\
\hline 122 & $\begin{array}{c}17.9 \pm 2.1 \\
(18)\end{array}$ & $\begin{array}{c}50.9^{b} \pm 2.6 \\
(18)\end{array}$ & $\begin{array}{c}367^{b} \pm 32 \\
(18)\end{array}$ & $\begin{array}{c}15.3 \pm 3.2 \\
(16)\end{array}$ & $\begin{array}{c}46.9^{b} \pm 2.9 \\
(16)\end{array}$ & $\begin{array}{c}350^{b} \pm 36 \\
(16)\end{array}$ & $\begin{array}{c}16.7 \pm 2.3 \\
(34)\end{array}$ & $\begin{array}{c}48.9^{b} \pm 2.9 \\
(34)\end{array}$ & $\begin{array}{c}360^{b} \pm 16 \\
(34)\end{array}$ \\
\hline 131 & $\begin{array}{c}18.8 \pm 2.3 \\
(20)\end{array}$ & $\begin{array}{c}57.1^{\mathrm{a}} \pm 2.5 \\
(20)\end{array}$ & $\begin{array}{c}426^{\mathrm{a}} \pm 30 \\
(20)\end{array}$ & $\begin{array}{c}16.3 \pm 3.2 \\
(18)\end{array}$ & $\begin{array}{c}53.8^{\mathrm{a}} \pm 2.9 \\
(18)\end{array}$ & $\begin{array}{c}411^{\mathrm{a}} \pm 35 \\
(18)\end{array}$ & $\begin{array}{c}17.6 \pm 1.9 \\
(38)\end{array}$ & $\begin{array}{c}55.6^{\mathrm{a}} \pm 2.5 \\
(38)\end{array}$ & $\begin{array}{c}420^{\mathrm{a}} \pm 18 \\
(38)\end{array}$ \\
\hline 143 & $\begin{array}{c}18.1 \pm 2.1 \\
(11)\end{array}$ & $\begin{array}{c}53.8^{\mathrm{b}} \pm 2.9 \\
(11)\end{array}$ & $\begin{array}{c}396^{b} \pm 29 \\
(11)\end{array}$ & $\begin{array}{c}15.3 \pm 2.8 \\
(18)\end{array}$ & $\begin{array}{c}48.9^{b} \pm 2.8 \\
(18)\end{array}$ & $\begin{array}{c}374^{\mathrm{b}} \pm 26 \\
(18)\end{array}$ & $\begin{array}{c}16.3 \pm 1.9 \\
(29)\end{array}$ & $\begin{array}{c}50.8^{\mathrm{b}} \pm 2.3 \\
(29)\end{array}$ & $\begin{array}{c}380^{b} \pm 19 \\
(29)\end{array}$ \\
\hline 2858 & $\begin{array}{c}18.9 \pm 2.5 \\
(6)\end{array}$ & $\begin{array}{c}54.7^{\mathrm{a}} \pm 2.8 \\
(6)\end{array}$ & $\begin{array}{c}496^{\mathrm{a}} \pm 19 \\
(6)\end{array}$ & $\begin{array}{c}14.6 \pm 3.2 \\
(5)\end{array}$ & $\begin{array}{c}56.9^{\mathrm{a}} \pm 3.7 \\
(5)\end{array}$ & $\begin{array}{c}479^{\mathrm{a}} \pm 26 \\
(5)\end{array}$ & $\begin{array}{c}16.9 \pm 1.8 \\
(11)\end{array}$ & $\begin{array}{c}55.7^{\mathrm{a}} \pm 2.1 \\
(11)\end{array}$ & $\begin{array}{c}430^{\mathrm{a}} \pm 22 \\
(11)\end{array}$ \\
\hline
\end{tabular}

ID, identity; SE, standard error; BWT, birth weight; FWT, final body weight; ADG, average daily gain and figures in the parenthesis indicate the number of observations. Means with different superscripts within the same column differed significantly $(p<0.05)$

Table 3. Average birth weight, final weight and daily gain of progeny of the different bulls at field levels

\begin{tabular}{|c|c|c|c|c|c|c|c|c|c|}
\hline \multirow{2}{*}{$\begin{array}{l}\text { Bull } \\
\text { ID }\end{array}$} & \multicolumn{3}{|c|}{ Male } & \multicolumn{3}{|c|}{ Female } & \multicolumn{3}{|c|}{ Pooled } \\
\hline & $\begin{array}{c}\mathrm{BWT} \pm \mathrm{SE} \\
(\mathrm{kg})\end{array}$ & $\begin{array}{c}\mathrm{FWT} \pm \mathrm{SE} \\
(\mathrm{kg})\end{array}$ & $\begin{array}{c}\mathrm{ADG} \pm \mathrm{SE} \\
\text { (g/day) }\end{array}$ & $\begin{array}{c}\mathrm{BWT} \pm \mathrm{SE} \\
(\mathrm{kg})\end{array}$ & $\begin{array}{c}\mathrm{FWT} \pm \mathrm{SE} \\
(\mathrm{kg})\end{array}$ & $\begin{array}{c}A D G \pm S E \\
(g / d)\end{array}$ & $\begin{array}{c}\mathrm{BWT} \pm \mathrm{SE} \\
(\mathrm{kg})\end{array}$ & $\begin{array}{c}\mathrm{FWT} \pm \mathrm{SE} \\
(\mathrm{kg})\end{array}$ & $\begin{array}{c}A D G \pm S E \\
(g / d)\end{array}$ \\
\hline 122 & $\begin{array}{c}15.6^{\mathrm{ab}} \pm 3.1 \\
(7)\end{array}$ & $\begin{array}{c}45.5 \pm 2.5 \\
\text { (7) }\end{array}$ & $\begin{array}{c}331 \pm 32 \\
(7)\end{array}$ & $\begin{array}{c}13.2^{\mathrm{ab}} \pm 3.2 \\
\text { (5) }\end{array}$ & $\begin{array}{c}40.6^{b} \pm 2.9 \\
\text { (5) }\end{array}$ & $\begin{array}{c}304^{b} \pm 31 \\
\text { (5) }\end{array}$ & $\begin{array}{c}14.6 \pm 3.5 \\
(12)\end{array}$ & $\begin{array}{c}43.4^{b} \pm 2.5 \\
(12)\end{array}$ & $\begin{array}{c}320^{c} \pm 30 \\
(12)\end{array}$ \\
\hline 131 & $\begin{array}{c}18.1^{\mathrm{a}} \pm 2.7 \\
(5)\end{array}$ & $\begin{array}{c}53.3 \pm 2.9 \\
(5)\end{array}$ & $\begin{array}{c}391 \pm 36 \\
(5)\end{array}$ & $\begin{array}{c}14.1^{\mathrm{a}} \pm 3.2 \\
(5)\end{array}$ & $\begin{array}{c}47.9^{\mathrm{a}} \pm 3.2 \\
(5)\end{array}$ & $\begin{array}{c}375^{\mathrm{a}} \pm 31 \\
\text { (5) }\end{array}$ & $\begin{array}{c}16.1 \pm 2.9 \\
(10)\end{array}$ & $\begin{array}{c}50.6^{\mathrm{a}} \pm 2.9 \\
(10)\end{array}$ & $\begin{array}{c}380^{b} \pm 32 \\
(10)\end{array}$ \\
\hline 143 & $\begin{array}{c}16.0^{\mathrm{ab}} \pm 3.5 \\
\text { (8) }\end{array}$ & $\begin{array}{c}54.2 \pm 3.1 \\
\text { (8) }\end{array}$ & $\begin{array}{c}24 \pm 31 \\
\text { (8) }\end{array}$ & $\begin{array}{c}11.1^{b} \pm 3.2 \\
(5)\end{array}$ & $\begin{array}{c}49.0^{\mathrm{a}} \pm 3.9 \\
\text { (5) }\end{array}$ & $\begin{array}{c}421^{a} \pm 39 \\
(5)\end{array}$ & $\begin{array}{c}14.1 \pm 3.5 \\
(13)\end{array}$ & $\begin{array}{c}52.2^{\mathrm{a}} \pm 3.3 \\
(13)\end{array}$ & $\begin{array}{c}420^{\mathrm{a}} \pm 30 \\
(13)\end{array}$ \\
\hline 2858 & $\begin{array}{c}14.9^{b} \pm 2.6 \\
\text { (4) }\end{array}$ & $\begin{array}{c}54.1 \pm 3.8 \\
(4)\end{array}$ & $\begin{array}{c}435 \pm 38 \\
(4)\end{array}$ & $\begin{array}{c}12.5^{\mathrm{ab}} \pm 4.0 \\
\text { (3) }\end{array}$ & $\begin{array}{c}47.8^{\mathrm{a}} \pm 4.5 \\
\text { (3) }\end{array}$ & $\begin{array}{c}393^{a} \pm 39 \\
\text { (3) }\end{array}$ & $\begin{array}{c}13.9 \pm 2.8 \\
(7)\end{array}$ & $\begin{array}{c}51.4^{\mathrm{a}} \pm 3.8 \\
\text { (7) }\end{array}$ & $\begin{array}{c}420^{\mathrm{a}} \pm 40 \\
\text { (7) }\end{array}$ \\
\hline
\end{tabular}

ID, identity; SE, standard error; BWT, birth weight; FWT, final body weight; ADG, average daily gain and figures in the parenthesis indicate the number of observations. Means with different superscripts within the same column differed significantly $(p<0.05)$

Table 4. Mean birth weight, final weight and average daily gain of calves at farm and field levels

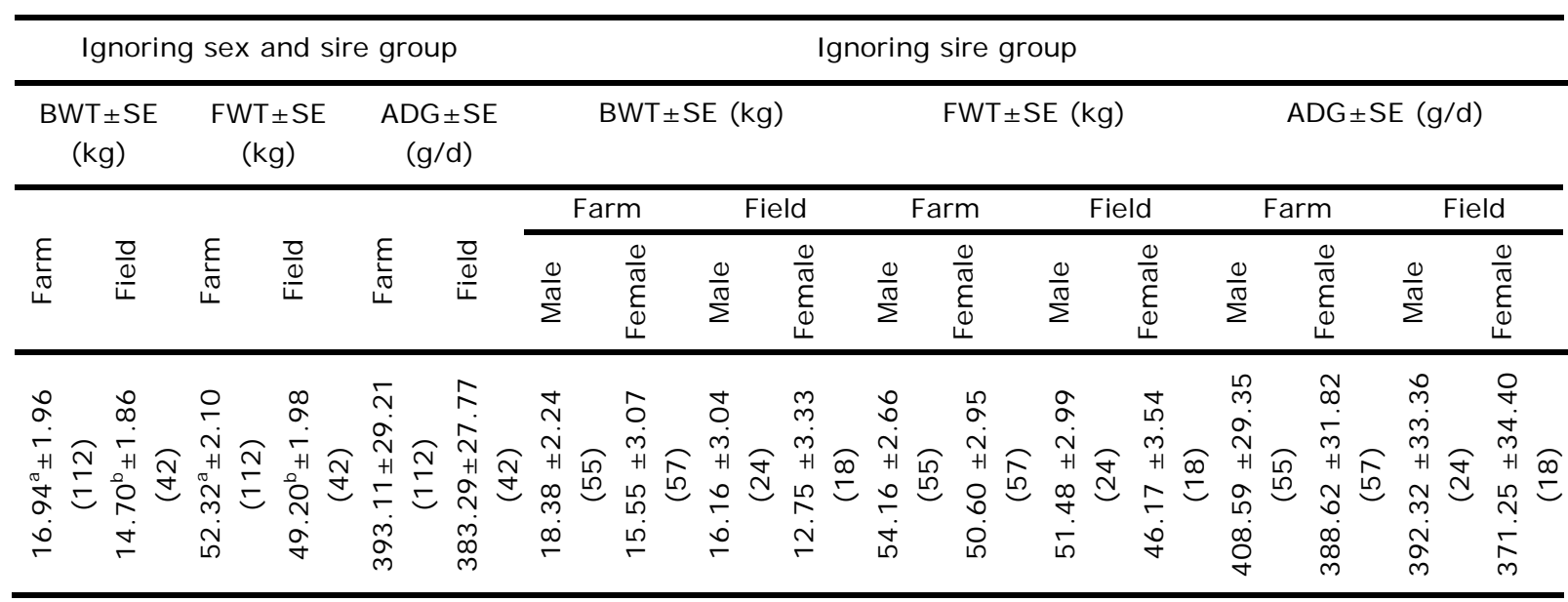

BWT, birth weight; FWT, final weight; ADG, average daily gain; SE, standard error; and Means with different superscripts differed significantly $(p<0.05)$; figures in the parentheses indicate the number of observation 
Hoque et al. (2013) Bang. J. Anim. Sci. 42 (2): 1 - 8

Table 5. Heritability of progeny traits and genetic correlations of traits between farm and field progeny

\begin{tabular}{llllll}
\hline \multirow{2}{*}{ Parameters } & & \multicolumn{3}{l}{ Field progeny } \\
\cline { 3 - 5 } & & & BWT & FWT & ADG \\
\hline \multirow{3}{*}{ Farm progeny } & $\mathrm{h}^{2} \pm \mathrm{SE}$ & *Pooled data & $0.32 \pm 0.19$ & $0.26 \pm 0.18$ & $0.29 \pm 0.20$ \\
\cline { 2 - 5 } & \multirow{3}{*}{$\mathrm{r}_{\mathrm{g}} \pm \mathrm{SE}$} & BWT & $0.86 \pm 0.21$ & $0.75 \pm 0.32$ & $0.91 \pm 0.31$ \\
& & FWT & $0.89 \pm 0.20$ & $0.78 \pm 0.30$ & $0.89 \pm 0.28$ \\
& ADG & $0.82 \pm 0.26$ & $0.82 \pm 0.29$ & $0.93 \pm 0.10$ \\
\hline
\end{tabular}

Table 6. Genetic correlations between growth traits of progeny (pooled data of farm and field level) and bull traits

\begin{tabular}{llll}
\hline Progeny & \multicolumn{3}{c}{ Bull traits $\left(r_{g} \pm S E\right)$} \\
\cline { 2 - 4 } traits & MWT & FI & RFI \\
\hline BWT & $0.54 \pm 0.17$ & $0.45 \pm 0.22$ & $0.06 \pm 0.18$ \\
FWT & $0.26 \pm 0.18$ & $0.38 \pm 0.24$ & $0.10 \pm 0.21$ \\
ADG & $0.28 \pm 0.23$ & $0.35 \pm 0.25$ & $-0.13 \pm 0.17$ \\
\hline
\end{tabular}

BWT, birth weight; FWT, final weight; ADG, average daily gain; MWT, metabolic body weight; FI, feed intake; RFI, residual feed intake.

\section{Heritability and genetic correlations}

Heritability of progeny traits and genetic correlations of traits between farm and filed progeny is shown in Table 5 . Average heritability pooled data for BWT, FWT and ADG was $0.32 \pm 0.19,0.26 \pm 0.18$ and $0.29 \pm 0.20$, respectively. The genetic correlations between the BWT for field progeny with the BWT, FWT and ADG of farm progeny were $0.86 \pm 0.21,0.89 \pm 0.20$ and $0.82 \pm 0.26$, respectively. Similarly the correlations between FWT of field progeny with BWT, FWT and ADG of farm progeny were $0.75 \pm 0.32, \quad 0.78 \pm 0.30$ and $0.82 \pm 0.29$, respectively. Once more these correlations between ADG of field progeny with the BWT, FWT and ADG of farm progeny were 0.91 \pm 0.31 , $0.89 \pm 0.28$ and $0.93 \pm 0.10$, respectively.

Genetic correlations ( $\left.r_{g} \pm S E\right)$ between early growth traits for pooled mean BWT, FWT and ADG of farm and field progeny, and bull traits for MWT, FI and RFI is presented in Table 6. The genetic correlation between MWT of bull with BWT, FWT and ADG of progeny were $0.54 \pm 0.17$, $0.26 \pm 0.18$ and $0.28 \pm 0.23$, respectively. Likewise the correlations between FI, and BWT, FWT and ADG were $0.45 \pm 0.22,0.38 \pm 0.24$ and $0.35 \pm 0.25$, respectively. Equally the correlations between the RFI of bull with the BWT, FWT and ADG of progeny were $0.06 \pm 0.18,0.10 \pm 0.21$ and $-0.13 \pm 0.17$, respectively.

\section{Discussion}

The estimated value of mean BWT was comparable to the value observed by Aktar et al. (2011) at farm level. They used breeding bulls like 122, 131, 143 and 2858 (those were also used in present experiment) and found mean BWT of $16.43 \pm 2.50,17.51 \pm 2.09,16.15 \pm 2.01$ and $17.71 \pm 1.89 \mathrm{~kg}$, respectively at BAU dairy farm (DF). Nahar et al. (1992) reported the average BWT of different genetic groups like Sahiwal $\times$ Local, Sindhi $x$ Local, Jersey $\times$ Local and Holstein $\times$ Local under rural condition as $17.6 \pm 0.3,16.1 \pm 0.2,17.7 \pm 0.2$ and $21.4 \pm 0.2 \mathrm{~kg}$, respectively. But this result was somewhat be higher to the present experiment at field level. Another study on birth weight of Red Chittagong cattle by Khan et al. (2000) reported to be 17.28 and $16.00 \mathrm{~kg}$ at farm and rural levels, respectively which were also close to the present findings. Uddin (2001) and Bhuiyan et al. (1992) estimated mean BWT values of 20.95 and 21.18 $\mathrm{kg}$, respectively for local cattle at farm level, both of which were higher than the present findings at farm level. An experiment was conducted by Bhuiyan (1999) using the data on Friesian and Friesian $x$ Local grades of cattle at the Central Cattle Breeding Station and Dairy Farm, Savar, Dhaka and recorded the average birth weight of $27.50 \pm 0.79$ and $23.05 \pm 0.32 \mathrm{~kg}$, respectively were heavier than the present records of both at farm and field levels.

Significantly $(p<0.05)$ higher FWT (Table 2$)$ was observed in farm progeny of bull ID No.131 and 2858 than that of the progeny of bull ID No. 122 and 143. The pooled FWT for field progeny (Table 3) of Friesian cross bulls ( 131 and 2858) and Sahiwal cross bulls (143) were significantly $(p<0.05)$ higher than the progeny of Sindhi cross bulls (122). The mean values of FWT for both of farm and field progeny range from $48.9 \pm 2.87$ to $55.67 \pm 2.14 \mathrm{~kg}$ and $43.43 \pm 2.50$ to $52.22 \pm 3.34$ $\mathrm{kg}$, respectively were greater than the value as $31.48 \mathrm{~kg}$ observed by Rabeya (2008). Coopman et al. (2007) found 98 and $96 \mathrm{~kg} \mathrm{FWT}$ of male 


\section{Effect of breeding bulls and genetic parameters on progeny growth}

and female, respectively for double-muscled Belgian Blue beef cattle that were remarkably higher than the present study.

Comparatively similar ADG was estimated for the progeny of bull ID No. 2858 at farm and field (Table 2 and 3) levels. The ADG for farm progeny range from $0.36 \pm 0.03$ to $0.43 \pm 0.01 \mathrm{~g} / \mathrm{d}$ (Table 2) was almost similar to the values of $0.36 \pm 0.02$ to $0.42 \pm 0.03 \mathrm{~g} / \mathrm{d}$ was observed by Aktar et al. (2011) although their observation slightly varied with the values of $0.32 \pm 0.03$ to $0.42 \pm 0.04 \mathrm{~g} / \mathrm{d}$ (Table 3) for field progeny of the present study. Hoque et al. (2006) estimated an ADG of $1.23 \pm 0.01 \mathrm{~g} / \mathrm{d}$ for Japanese Black cattle was immensely higher than that found for both of farm and field progeny in present investigation.

Ignoring sex and sire group, the mean BWT (Table 4) for farm progeny was significantly $(p<0.05)$ higher than the field, but these values (both for farm and field) were lower than the values $(17.15 \pm 2.25$ and $16.46 \pm 2.19 \mathrm{~kg}$ for male and female, respectively) established by Aktar et al. (2011). Habib et al. (2003) observed $16.7 \pm 0.48 \mathrm{~kg}$ BWT for Red Chittagong cattle was almost similar to $16.94 \pm 1.96 \mathrm{~kg}$, though somewhat higher to $14.70 \pm 1.86 \mathrm{~kg}$ found in present study. In considering sex, there was no remarkable variation of BWT of Aktar et al. (2011) and those found in present study for both levels with an exception for female progeny at field level (Table 4).

\section{Heritability and genetic correlations}

The estimated mean heritability was moderate $(0.32 \pm 0.19)$ and close to moderate $(0.29 \pm 0.20)$ for BWT and ADG, respectively which agreed to the heritability found $(0.30 \pm 0.20)$ by Aktar et al. (2011), but low $(0.26 \pm 0.18)$ for FWT. Akbulut et al. (2002) estimated a corresponding heritability value of $0.29 \pm 0.148$ for Brown Swiss calves. Oikawa et al. (2000) estimated heritability (0.20 to 0.38 ) for growth traits, which were in between the range of present study (Table 5). Kemp et al. (1988) and Tosh et al. (1999) observed heritability of 0.19 and 0.15 , respectively for BWT were lower than the present values.

The genetic correlation between bull MWT with progeny BWT was moderately high $\left(r_{g}=0.54\right)$, but the correlations with FWT $\left(r_{g}=0.26\right)$ and ADG $\left(r_{g}=0.28\right) \quad$ were low. The present value $(0.28 \pm 0.23)$ of genetic correlation between ADG and MWT was lower than value of $0.37 \pm 1.24$ estimated by Aktar et al. (2011), however, Hoque et al. (2005) showed extremely higher result $(0.96 \pm 0.09)$ than in the present study. The estimated heritability for ADG $(0.30 \pm 0.10)$ simply agreed to the value observed by Hoque et al. (2005) in Japanese Black bulls. Other corroborated values as 0.22 by Hirooka et al. (1996), $0.20 \pm 0.09$ by Oikawa et al. (2000) for Japanese Black steers and 0.20 by Hoque et al. (2006) for Japanese Black young bulls supported the present results. Arthur et al. (2001) concluded that the ADG to be moderately heritable (0.20) which was slightly less than the present observation. Uchida et al. (2001) analyzed heritability for performance traits in Japanese Black steers and found the heritability of ADG to be 0.57 , which is considerably higher than the present result.

The $\mathrm{FI}$ for bulls were moderately correlated with BWT (0.45 \pm 0.22$)$, FWT $(0.38 \pm 0.24)$ and ADG $(0.35 \pm 0.25)$ of their progeny. Shojo et al. (2005) estimated the heritability for growth and feed utilization traits in Japanese Black cattle and ranged from 0.40 to 0.70 was visibly higher in the present study. Archer et al. (2002) established that $\mathrm{FI}$ and ADG for heifers and mature cows to be strongly correlated as $r_{g}=0.94$ and $r_{g}=0.72$, respectively. A negative genetic correlation $\left(r_{g}=-0.13 \pm 0.17\right)$ was estimated between ADG and RFI (Table 6) that was in agreement with the figure of $-0.10 \pm 0.18$ as observed by Aktar et al. (2011). There was positive but very low correlation found between RFI, and BWT $(0.06 \pm 0.18)$ vs. FWT $(0.10 \pm 0.21)$ (Table 6). The correlation between RFI with BWT of the progeny was close to zero $(0.06 \pm 0.18)$ and well comparable to the $0.08 \pm 0.22$ established by Aktar et al. (2011). Hoque et al. (2005) established a correlation of bull RFI with body weights of their progeny were -0.33 at starting the test and -0.61 at finishing. Thus their conclusion was that a favorable negative genetic correlation between RFI and body weights of the progeny indicated the selection for lower RFI (higher feed efficiency) of bulls would lead to an increase in body weights of their progeny. The results by Korver et al. (1991) results for RFI with ADG and body weight were also close to zero and kept consistency with the present result.

\section{Conclusion}

Residual feed intake may serve as an appropriate selection tool for improving feed efficiency of 
breeding bulls without adversely affecting early growth performance of the progeny. Though residual feed intake of bulls is independent (zero correlation) with BWT, but weak and negative correlation with ADG of their progeny suggests that selection for reduced residual feed intake may result in improved animal efficiency without increasing cow size and it is possible to decrease residual feed intake of bulls without compromising progeny performance to improve herd production efficiency. Further in depth study with large number of animals is indeed for drawing authentic and sensible decision.

\section{Acknowledgment}

Major funding for this research has been provided through a grant from Bangladesh Agricultural University Research System (BAURES). The logistic support received from the Department of Animal Breeding and Genetics and Dairy Farm of Bangladesh Agricultural University, Mymensingh were gratefully acknowledged.

\section{References}

Ahola JK, Campbell LT, Szasz JI, Skow TA, Hunt CW, Glaze JB and Hill RA (2007). Relationship between residual feed intake and meat quality in steer progeny of divergent intramuscular fat EPD Angus bulls. Proceedings, Western Section. American Society of Animal Science, 58: 195-199.

Akbulut O, Bayram B, Tuzemen N and Aydn R (2002). Phenotypic and genetic parameter estimates of Brown Swiss calves for birth weight and somebody measurements at birth. Ziraat Fakultesi Dergisi Ataturk Universitesi, 33: 59-64.

Aktar S, Bhuiyan AKFH, Saha NG and Hoque MA ( 2011). Effect of bull performance on progeny early growth and genetic relationships between bull and progeny traits. Bangladesh J ournal of Animal Science, 40: 1-7.

Archer JA, Reverter A, Herd RM, Johnston DJ and Arthur PF (2002). Genetic variation in feed intake and efficiency of mature beef cows and relationships with post-weaning measurements. Proceedings of the seventh World Congress on Genetics Applied to Livestock Production, France, 31: 221-224.

Arthur PF, Archer JA, Herd RM and Melville GJ (2001). Response to selection for net feed intake in beef cattle. Proceedings of the Association of Animal Breeding. 14: 135138.
Bhuiyan MSA (1999). Estimation of genetic parameters for some economic traits of dairy cattle. MS Thesis, Department of Animal Breeding and Genetics, Bangladesh Agricultural University, Mymensingh.

Bhuiyan AKFH, Matin MA and Faruq MO(1992). Performance of purebred and crossbred dairy cattle in Bangladesh. Proceedings of the $6^{\text {th }}$ AAPP Animal Science Congress, 8: 182.

Coopman F, Krafft A, Dewul FJ, Zeveren A, Gengler $N$ (2007). Estimation of Phenotypic and genetic parameters for weight gain and weight at fixed ages in the double-muscled Belgian Blue Beef breed using field records. Journal of Animal Breeding and Genetics, 124: 20-25.

Habib MA, Bhuiyan AKFH, Bhuiyan MSA and Khan AA (2003). Performance of Red Chittagong cattle in Bangladesh Agricultural University Dairy Farm. Bangladesh Journal of Animal Science, 32: 101-108.

Hirooka H, Groen AF, Matsumoto M (1996). Genetic parameters for growth and carcass traits in Japanese Brown cattle estimated from field records. Journal of Animal Science, 74: 251260.

Hoque MA, Arthur PF, Hiramoto K, Oikawa T (2006). Genetic relationship between different measures of feed efficiency and it component traits in Japanese Black (Wagyu) bulls. Livestock Science, 99: 111118.

Hoque MA, Hiramoto K, Oikawa T (2005). Genetic relationship of feed efficiency traits of bulls with growth and carcass traits of their progeny for Japanese Black (Wagyu) cattle. Animal Science Journal. Melbourne, Australia: Blackwell Publishing, 76: 107-114.

Hoque MA, Oikawa T (2004). Comparison and relationship among the different estimates of the residual feed intake of Japanese Black (Wagyu) bulls. Animal Science Journal, 75: 201-205.

Kemp RA, Wilton JW, Schaeffer LR (1988). Phenotypic and genetic parameter estimates for gestation length, calving case and birth weight in Simmental cattle. Canadian Journal of Animal Science, 68: 291-294.

Khan MKI, Haque KS, Mian AG, Khatun MJ (2000). Study on the performance of Red Chittagong cows under different production system. Pakistan Journal of Biological Science, 3: 318-319.

Koch RM, Swiger LA, Chambers D, Gregory KE (1963). Efficiency of feed use in beef 


\section{Effect of breeding bulls and genetic parameters on progeny growth}

cattle. Journal of Animal Science, 22: 486494.

Korver S, Eekelen EAM, Vos $\mathrm{H}$, Nieuwhof GJ and Arendonk JA M( 1991). Genetic aspects of feed intake and feed efficiency in growing dairy heifers. Livestock Production Science, 29: 49-59.

Lancaster PA, Carstens GE, Crews DH, Woods SA (2005). Evaluation of feed efficiency traits in growing bulls and relationship with feeding behavior and ultrasound carcass estimates. Proceedings, Western Section, American Society of Animal Science, 56.

Nahar TN, Islam M, Hasnath MA (1992). A quantitative study on the performance of $F_{1}$ graded cows under rural conditions. Asian-Australasian Journal of Animal Science, 5: 435-438.

Neumarier A, Groeneveld EG (1998). Residual Maximum Likelihood estimation of covariances in sparse linear models. Genetics Selection Evolution, 30: 3-26.

Oikawa T, Sanehira T, Sato K, Mizoguchi Y, Yamamoto H, Baba M (2000). Genetic parameters for growth and carcass traits of Japanese Black (Wagyu) cattle. Journal of Animal Science, 71: 59-64.

Rabeya T (2008). Phenotypic and genetic parameters on growth traits of Red Chittagong Cattle. MS Thesis, Department of Animal Breeding and Genetics, Bangladesh Agricultural University, Mymensingh.
SAS (1998). User's guide. SAS Institute Inc Version 6.12. Cary. United States of America.

Shojo M, Yong J, Anada K, Oyama K, Mukai F (2005). Estimation of genetic parameters for Sgrowth and feed utilization traits in Japanese Black cattle. Animal Science Journal, 76: 115-119.

Tosh JJ, Kemp RA and Ward DR (1999). Estimation of direct and maternal genetic parameters for weight traits and back-fat thickness in a multibreed population of beef cattle. Canadian Journal of Animal Science, 79: 433-439.

Trejo CO (2010). Residual feed intake, breed of sire and dam, and individual sire affect performance and carcass characteristics and rates of back fat and intramuscular fat of feedlot steers. Ph.D Thesis. Department of Animal Science, University of Illinois, Urbana.

Uchida H, Oikawa T, Suzuki K, Yamagishi T (2001). Estimation of genetic parameters using an animal model for traits in performance and progeny testing for meat production of Japanese Black cattle herd in Miyagi prefecture. Animal Science Journal, 72: 89-96.

Uddin MM (2001). A comparative study on some productive and reproductive economic traits of different genetic groups of dairy cows in Military Farm, and Central Cattle Breeding Station, Savar, Dhaka. MS Thesis. Department of Dairy Science, Bangladesh Agricultural University, Mymensingh. 